\title{
THEORETICAL STUDY OF THE MECHANISM GENERATING AZOMETHINE YLIDE FROM FORMALDEHYDE AND GLYCINE
}

\author{
P. Wu \\ Department of Chemistry, Dezhou College, Shandong; Key Laboratory of Coordination Chemistry and Functional \\ Materials at Universities of Shandong, P. R. China \\ E-mail: Pingwu.dzu@gmail.com
}

Received March, 9, 2014

\begin{abstract}
The mechanism to generate azomethine ylide from formaldehyde and glycine is systematically investigated. The density functional theory at the B3LYP/6-311++G $(d, p)$ level is employed for both geometry optimization and single point energy calculation. Our results indicate that two possible pathways can lead to the generation of the carbinolamine intermediate with a favorable step-wise pathway. However, as for the step to form azomethine ylide, a concerted elimination of water and carbon dioxide is preferred. This calculation result is totally different from the widely accepted revised Rizzi mechanism.
\end{abstract}

DOI: $10.15372 / J S C 20150705$

K e y w o r d s: azomethine ylide, B3LYP/6-311++G( $d, p)$, formaldehyde, glycine.

Azomethine ylides have been widely applied to synthesize nitrogen-containing pyrrolidines or pyrrolines for organometallic catalysis and natural product synthesis [ $1-3]$. Due to their instability, azomethine ylides are usually generated in situ by thermolysis or photolysis of aziridines [4], desilylation [5], tautomerization of imines [6], deprotonation of iminium salts [7], decarboxylation from the corresponding aldehydes and amino acids [8], etc. As for the decarboxylation route, the widely accepted mechanism, also known as the revised Rizzi mechanism, is shown in Scheme 1 [ 8 ]. A carbinolamine intermediate is formed, followed by the elimination of a water molecule to give a zwitterion that cyclizes into a thermally labile 5-oxazolidinone intermediate before the thermal decarboxylation to generate final azomethine ylide. While most theoretical investigations focused on the stereoselectivity of azomethine ylides with olefins [9], the mechanism of the generation of azomethine ylides from aldehydes and amino acids has not been investigated so far.

A related study on the zwitterion formation was reported in 2002 by Boyd's group in a prolinecatalyzed enantioselective aldol reaction [10]. The carboxylic group was considered to facilitate either the carbinolamine formation or the zwitterions generation step, but it was not considered important in both steps. As a continuation of our work [11 ], a systematic study of the azomethine ylide formation from formaldehyde and glycine was investigated in this paper and was calculated at the B3LYP/6-311++G $(d, p)$ level.
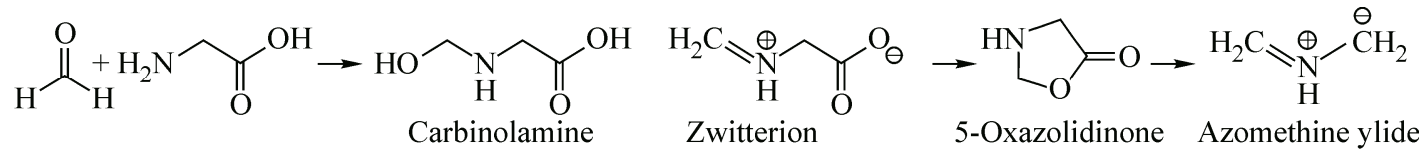

Scheme 1. Revised Rizzi's mechanism for the azomethine ylide formation from formaldehyde and glycine

(C) Wu P., 2015 


\section{CALCULATION PROCEDURE}

The computations were carried out using the Gaussian 03 (Reversion D.02) program package at the B3LYP/6-31++G( $d, p)$ level [12]. All zero-gradient structures were characterized by a vibrational analysis with no imaginary frequency. All of the transition state structures were confirmed to have only one imaginary frequency, which was interpreted as a negative vibrational mode, and the intrinsic reaction coordinate (IRC) $[13,14]$ was followed to make sure that each transition state connected the expected two minima.

\section{RESULTS AND DISCUSSION}

Our calculation results show that in addition to the revised Rizzi mechanism, a step-wise pathway for the carbinolamine formation (path 1) and a concerted elimination of water and carbon dioxide (path 5) must be taken into account, as is summarized in Scheme 2.

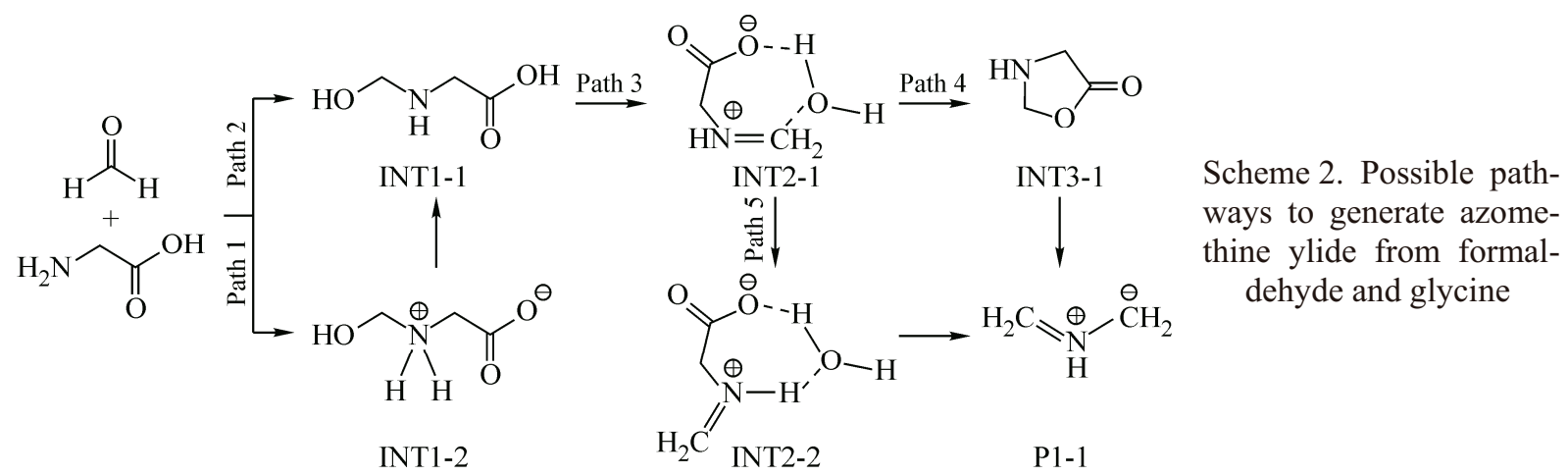

Structures of the transition states, intermediates, and products are shown in Scheme 3 with selected bond lengths included, while the B3LYP/6-311++G $(d, p)$ calculated total Gibbs free energies $(\mathrm{G})$, together with the relative reaction energies are listed in Table 1.

Carbinolamine formation. Similarly to the previously reported imine formation calculations [15], the carbinolamine formation from formaldehyde and glycine proceeds through a concerted proton transfer reaction from the glycine nitrogen atom to the formaldehyde oxygen atom via a fourmembered ring transition state (TS1-1) which lies $41.59 \mathrm{kcal} \cdot \mathrm{mol}^{-1}$ above the reactants. The $\mathrm{C} 1-\mathrm{N} 1$ bond $(1.574 \AA)$ is well formed in TS1-1 and the $\mathrm{N} 1-\mathrm{H} 1$ and $\mathrm{O} 1-\mathrm{H} 1$ distances are $1.198 \AA$ and $1.405 \AA$, respectively. Moreover, as implied by the Boyd group [10 ], a self-catalyzed pathway, involving the carboxylic group, is found to facilitate the carbinolamine formation through a sevenmembered ring transition state (TS1-2) which is only $23.06 \mathrm{kcal} \cdot \mathrm{mol}^{-1}$ higher than the reactants. The

T a b l e 1

B3LYP/6-31++G( $(d, p)$ calculated Gibbs free energies (au) and relative reaction energies $\left(\mathrm{kcal} \cdot \mathrm{mol}^{-1}\right.$ ) for the azomethine ylide formation from formaldehyde and glycine ${ }^{a}$

\begin{tabular}{|c|c|c|c|c|c|c|c|c|}
\hline Label & G & $\Delta G^{\ddagger a}$ & Label & G & $\Delta G^{\ddagger a}$ & Label & G & $\Delta G^{\ddagger a}$ \\
\hline Formaldehyde & -114.536334 & & TS1-3 & -398.978800 & 23.06 & TS4-1 & -322.525379 & $22.15^{c}$ \\
\hline Glycine & -284.479221 & & TS2-1 & -398.977453 & 23.91 & P1-1 & -133.893738 & $6.91^{d}$ \\
\hline TS1-1 & -398.949271 & 41.59 & INT2-1 & -398.980488 & 22.00 & TS3-2 & -398.982691 & 20.62 \\
\hline INT1-1 & -399.011157 & 2.76 & INT2-2 & -398.988482 & 16.99 & $\mathrm{H}_{2} \mathrm{O}$ & -76.454884 & \\
\hline TS1-2 & -398.978819 & 23.05 & TS3-1 & -398.979977 & 22.33 & $\mathrm{CO}_{2}$ & -188.65592 & \\
\hline INT1-2 & -398.979124 & 22.86 & INT3-1 & -322.561355 & $-0.43^{b}$ & & & \\
\hline
\end{tabular}

\footnotetext{
${ }^{a}$ Relative reaction energies $\left(\Delta G^{\ddagger}\right)$ are referred to the sum of formaldehyde and glycine.

${ }^{b}$ Sum values of INT3-1 and water referred to formaldehyde and glycine.

${ }^{c}$ Sum values of TS4-1 and water referred to formaldehyde and glycine.

${ }^{d}$ Sum values of P1-1, water, and carbon dioxide referred to formaldehyde and glycine.
} 

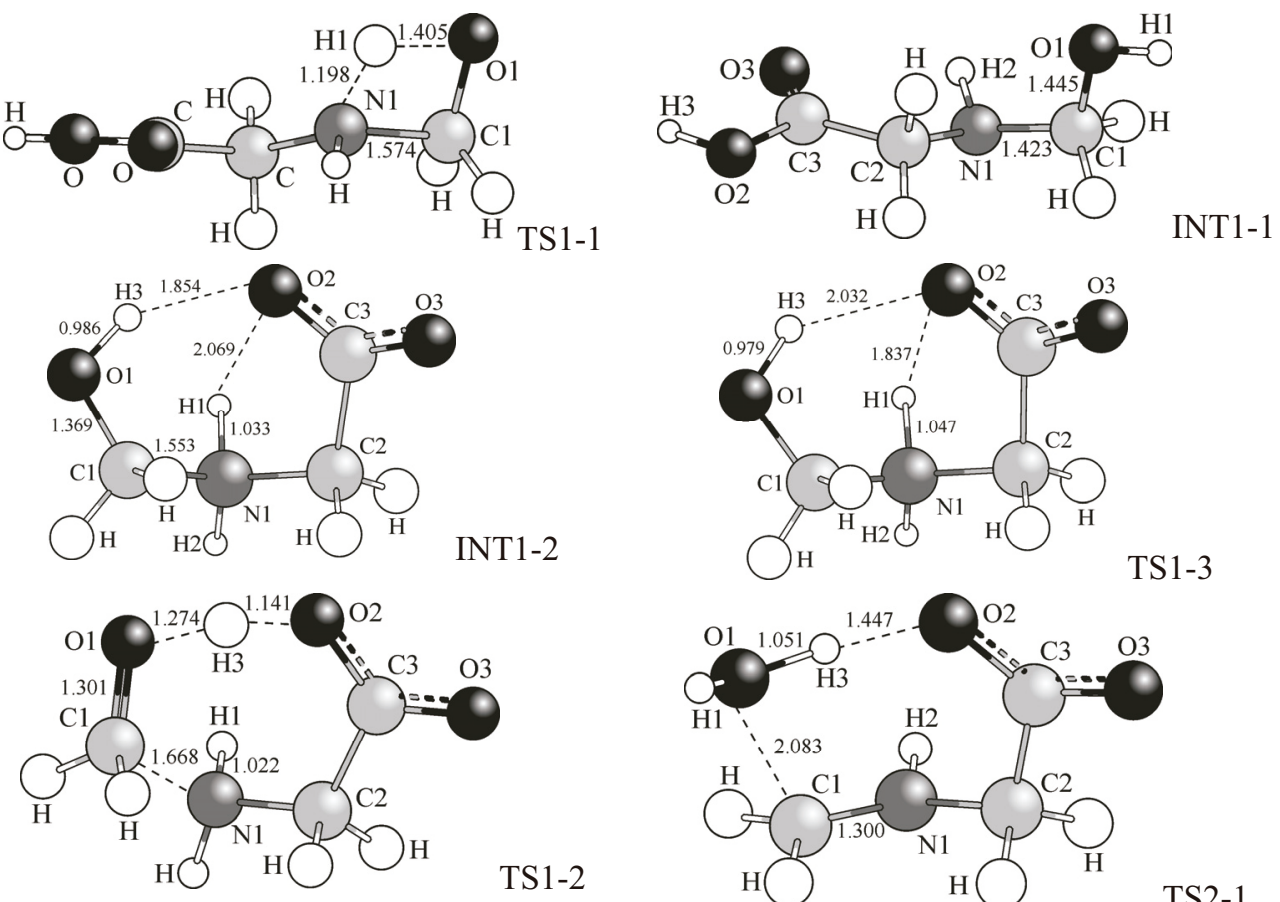

TS1-2

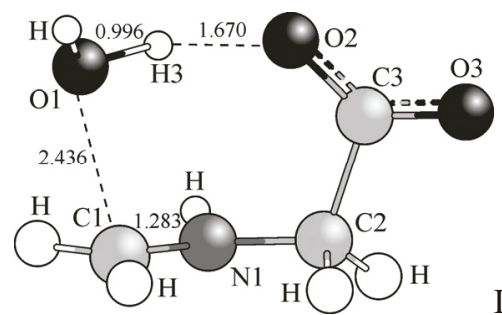

INT2-1

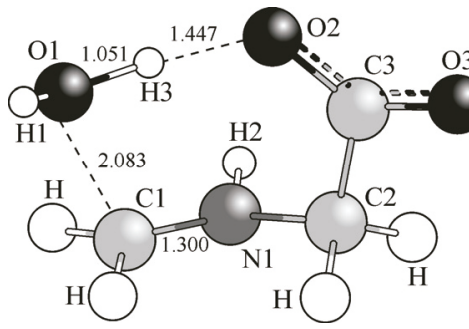

TS2-1
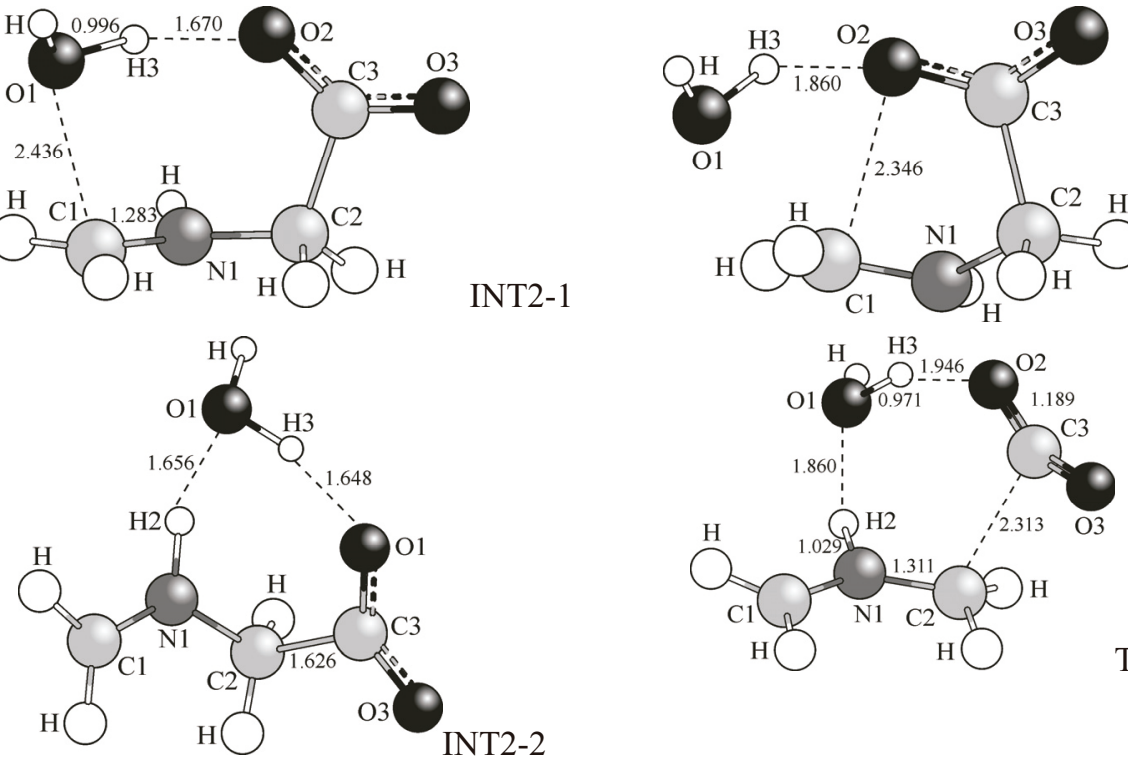

TS3-1

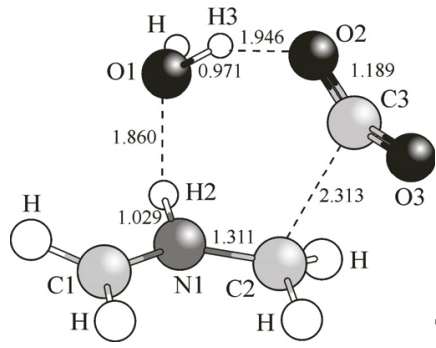

TS3-2
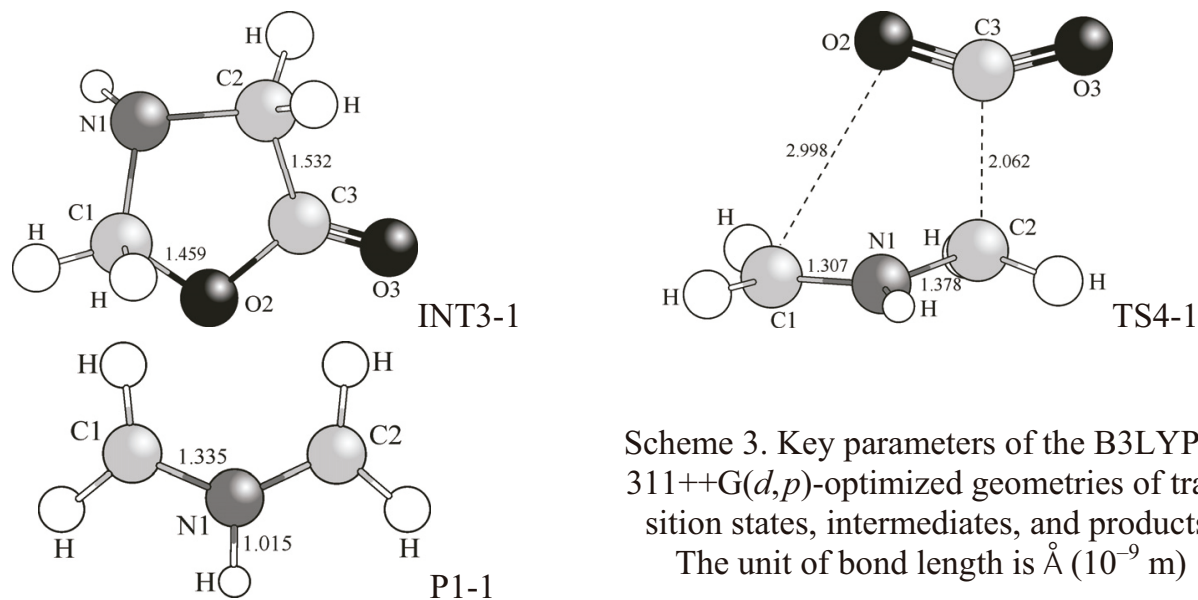

Scheme 3. Key parameters of the B3LYP/6$311++\mathrm{G}(d, p)$-optimized geometries of transition states, intermediates, and products.

The unit of bond length is $\AA\left(10^{-9} \mathrm{~m}\right)$ 


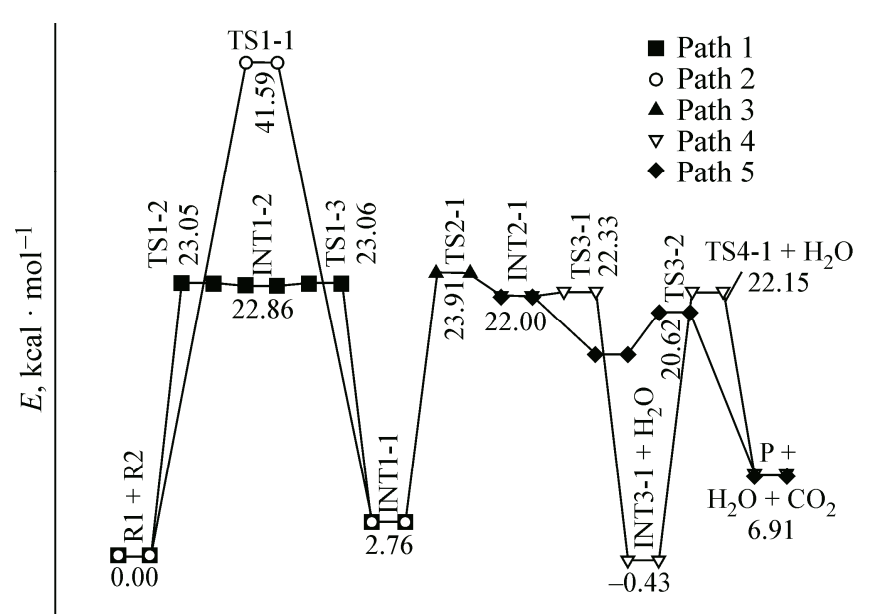

Fig. 1. Energy profile for the generation of azomethine ylide from formaldehyde and glycine at the B3LYP/6-311++G $(d, p)$ level

$\mathrm{C} 1-\mathrm{N} 1$ bond is slightly longer $(1.668 \AA)$, and the $\mathrm{O} 2-\mathrm{H} 3$ and $\mathrm{O} 1-\mathrm{H} 3$ bonds are $1.141 \AA$ and $1.274 \AA$ respectively, indicating that the $\mathrm{H} 3$ proton leaves $\mathrm{O} 2$ to combine with $\mathrm{O} 1$. The IRC analysis reveals that TS1-2 leads to the INT1-2 intermediate which is only $0.19 \mathrm{kcal} \cdot \mathrm{mol}^{-1}$ more stable than TS1-2. INT1-2 has a $1.553 \AA \mathrm{C} 1-\mathrm{N} 1$ bond and the $\mathrm{O} 1-\mathrm{H} 3$ bond is $0.986 \AA$. A pass through TS1-3, INT1-2 will lead to INT1-1 by the proton transfer from the iminium nitrogen atom to the carboxylate group. Although TS1-3 has a very similar structure to INT1-2, the IRC analysis does connect INT1-2 and INT1-1 through TS1-3. In TS1-3, while the $\mathrm{N} 1-\mathrm{H} 1$ distance is lengthened by $0.014 \AA(1.033$ vs. $1.047 \AA)$, the $\mathrm{O} 2-\mathrm{H} 1$ bond is shortened to $1.837 \AA$ from $2.069 \AA$. Meanwhile, the separation between $\mathrm{O} 2$ and $\mathrm{H} 3$ atoms increases from $1.854 \AA$ to $2.032 \AA$. The energy barrier for TS1-3 differs by only $0.2 \mathrm{kcal} \cdot \mathrm{mol}^{-1}$ from that of INT1-2. The final INT1-1 intermediate is $2.76 \mathrm{kcal} \cdot \mathrm{mol}^{-1}$ more endothermic, as compared to the reactants.

The energy profile for the azomethine ylide generation from formaldehyde and glycine is depicted in Fig. 1, which clearly indicates that the carboxylic group participation in seven-membered transition states is favored by at least $18.53 \mathrm{kcal} \cdot \mathrm{mol}^{-1}$.

Zwitterion formation. The elimination of a water molecule from INT1-1 was also found to pass through a seven-membered ring transition state (TS2-1) which has an energy barrier of $21.15 \mathrm{kcal} \cdot \mathrm{mol}^{-1}$. In TS2-1, the $\mathrm{C} 1-\mathrm{N} 1$ bond is shortened to $1.300 \AA$, indicating a double bond formation, while the $\mathrm{C} 1-\mathrm{O} 1$ bond is broken $(\mathrm{C} . . \mathrm{O}$ is $2.083 \AA)$. Meanwhile, the $\mathrm{H} 3$ proton combines with the hydroxyl group to generate a water molecule. The IRC analysis of TS2-1 ends up with the INT2-1 complex as a local minimum with the $\mathrm{C} 1-\mathrm{O} 1$ and $\mathrm{O} 2-\mathrm{H} 3$ bonds of $2.436 \AA$ and $1.670 \AA$ respectively. Furthermore, we tried to locate a transition state for the generation of a water molecule from INT1-2 to produce INT2-1 directly, but failed. Only TS2-1 is found to form a water molecule from INT1-1 to the INT2-1 complex.

Azomethine ylide formation. INT2-1 has two ways to reach P1-1. One is the formation of a 5-oxazolidinone intermediate, then thermally decarboxylate to P1-1 (Path 4); the other one starts with a geometry transformation to INT2-2, followed by a concerted elimination of water and carbon dioxide (Path 5). For the first pathway, INT3-1 was obtained from INT2-1 via a TS3-1 transition state, which differs only by $0.33 \mathrm{kcal} \cdot \mathrm{mol}^{-1}$ from INT2-1. In TS3-1, the $\mathrm{C} 1-\mathrm{O} 2$ bond is $2.346 \AA$, while the $\mathrm{H} 3-\mathrm{O} 2$ hydrogen bond is found to be $1.860 \AA$. INT3-1 is a very stable intermediate which is $22.76 \mathrm{kcal} \cdot \mathrm{mol}^{-1}$ more exothermic than TS3-1. TS4-1 is nearly at the same energy level as TS3-1 ( 22.15 vs. $22.33 \mathrm{kcal} \cdot \mathrm{mol}^{-1}$ ). While the $\mathrm{C} 2-\mathrm{C} 3$ bond is $2.062 \AA$, the $\mathrm{C} 1-\mathrm{O} 2$ distance is $2.998 \AA$, indicating that $\mathrm{C} 1$ and $\mathrm{O} 2$ are completely dissociated and carbon dioxide is ready to leave. The final product (azomethine ylide) is $6.91 \mathrm{kcal} \cdot \mathrm{mol}^{-1}$ above the reactants, thus being an unstable product, which also explains why azomethine ylides were always generated in situ.

As for path 5, INT2-1 first converts to INT2-2 by changing its conformation from the C1... O1 weak interaction $(2.436 \AA)$ to the $\mathrm{O} 1-\mathrm{H} 2$ hydrogen bond $(1.656 \AA)$. Meanwhile, another $\mathrm{O} 2-\mathrm{H} 3$ hydrogen bond is also slightly lengthened from $1.670 \AA$ to $1.648 \AA$. The total energy is lowered by $5.01 \mathrm{kcal} \cdot \mathrm{mol}^{-1}$. The elongation of the $\mathrm{C} 2-\mathrm{C} 3$ distance from $1.626 \AA$ to $2.313 \AA$, together with the increased $\mathrm{O} 1-\mathrm{H} 2(1.860 \AA)$ and $\mathrm{O} 2-\mathrm{H} 3(1.946 \AA)$ hydrogen bonds, make TS3-2 be $3.63 \mathrm{kcal} \cdot \mathrm{mol}^{-1}$ higher than INT2-2. The simultaneous elimination of water and carbon dioxide finishes the azomethine ylide formation as $\mathrm{P} 1-1$, which is preferred by at least $18.95 \mathrm{kcal} \cdot \mathrm{mol}^{-1}$ as compared with path 4 . 


\section{CONCLUSIONS}

In this paper, a detailed mechanistic study of the azomethine ylide formation from formaldehyde and glycine has been carried out. Out of five possible pathways, the most favorable route would be the through the carboxylic group, involving seven-membered ring transition states, to carbinolamine and the following concerted elimination of water and carbon dioxide, i.e. path $1 \rightarrow$ path $3 \rightarrow$ path 5 .

This work is financially supported by the Natural Science Foundation of Shandong Province of China (No. ZR2009BL004). We also thank Key lab of Biophysics in Universities of Shandong for their computational resources.

\section{REFERENCES}

1. Padwa A. 1,3-Dipolar cycloaddition chemistry, Vols. 1,2. - New York: Wiley-Interscience, 1984. (b) Padwa A., Pearson W.H. Synthetic Applications of 1,3-Dipolar cycloaddition chemistry toward heterocycles and natural products, Inc. - New York: John Wiley \& Sons, 2002, Chapter 03. (c) Gothelf K.V., Jørgensen K.A. // Chem. Rev. - 1998. - 98. - P. 863. (d) Nájera C., Sansano J.M. // Current Organ. Chem. - 2003. - 7. - P. 1105. (e) Tsuge O., Kanemasa S. // Adv. Heterocycl. Chem. - 1989. - 45. - P. 231.

2. (a) Kogan V.A., Dorokhova N.I., Osipov O.A. // J. Struct. Chem. - 1971. - 12. - P. 1023. (b) Zelentsov V.V., Bogdanov A.P., Rukhadze E.G., Talyzenkova G.P. // J. Struct. Chem. - 1973. - 14. - P. 564. (c) Averyanov E.M. // J. Struct. Chem. - 1993. - 34. - P. 567. (d) Kozhevina L.I., Prokopenko E.B., Rybachenko V.I., Titov E.V. // J. Struct. Chem. - 1995. - 36. - P. 276. (e) Varnek V.A., Mazalov L.N., Uraev A.I., Nivorozhkin A.L., Garnovskii A.D. // J. Struct. Chem. - 2000. - 41. - P. 427.

3. (a) Gruzdev M.S., Chervonova U.V., Kolker A.M., Domrachev N.E. // J. Struct. Chem. - 2011. - 52. - P. 83. (b) Zhurko G.A., Aleksandriiskii V.V., Burmistrov V.A. // J. Struct. Chem. - 2011. - 52. - P. 227. (c) Gruzdev M.S., Chervonova U.V., Kolker A.M., Golubeva A.S. // J. Struct. Chem. - 2012. - 53. - P. 845. (d) Gruzdev M.S., Domracheva N.E., Aleksandrov A.I., Osipova V.P., Chervonova U.V., Kolker A.M., Pashkova T.V., Barakhtenko D.V. // J. Struct. Chem. - 2012. - 53. - P. 1062.

4. Heine H.W., Peavy R. // Tetrahedron Lett. - 1965. 3123. (b) Padwa A., Hamilton L. // Tetrahedron Lett. - 1965. - P. 4363. (c) Huisgen R., Scheer W., Szeimies G., Huber H. // Tetrahedron Lett. - 1966. - P. 397.

5. Vedejs E., Martinez G.R. // J. Am. Chem. Soc. - 1979. - 101. - P. 6452. (b) Deyrup J.A., Szabo W.A. // J. Org. Chem. - 1975. - 40. - P. 2048.

6. Huisgen R., Gotthardt H., Bayer H.O. // Angew. Chem. Int. Ed. Engl. - 1964. - 3. - P. 135. (b) Gotthardt H., Huisgen R., Bayer H.O. // J. Am. Chem. Soc. - 1970. - 92. - P. 4340. (c) Grigg R., Kemp J. // Chem. Commun. - 1977. - P. 125. (d) Grigg R., Kemp // J. Chem. Commun. - 1978. - P. 109.

7. Deyrup J.A., Szabo W.A. // J. Org. Chem. - 1975. - 40. - P. 2048. (b) Deyrup C.L., Deyrup J.A., Hamilton M. // Tetrahedron Lett. - 1977. - P. 3437. (c) Deyrup J.A., Kuta G.S. // J. Org. Chem. - 1978. - 43. - P. 501.

8. Rizzi G.P. // J. Org. Chem. - 1970. - 35. - P. 2069. (b) Zugravescu I., Petrovanu M. N-Ylide Chemistry. - New York: McGraw-Hill, 1976. (c) Eschenmoser A. // Chem. Soc. Rev. - 1976. - 5. - P. 377. (d) Seebach D., Boes M., Naef R., Schweizer W.B. // J. Am. Chem. Soc. - 1983. - 105. - P. 5390. (e) Tsuge O., Kanemasa S., Ohe M., Takenaka S. // Chem. Lett. - 1986. - P. 973. (f) Tsuge O., Kanemasa S., Ohe M., Takenaka S. // Bull. Chem. Soc. Jpn. - 1987. - 60. - P. 4079.

9. Domingo L.R. // J. Org. Chem. - 1999. - 64. - P. 3922. (b) Lu X., Tian F., Xu X., Wang N., Zhang Q. // J. Am. Chem. Soc. - 2003. - 125. - P. 10459. (c) Cao Y., Houk K.N. // J. Mater. Chem. - 2011. - 21. - P. 1503. (d) Ess D.H., Houk K.N. // J. Am. Chem. Soc. - 2008. - 130. - P. 10187. (e) Alimohammadi K., Sarrafi Y., Tajbakhsh M., Yeganegi S., Hamzehloueian M. // Tetrahedron. - 2011. - 67. - P. 1589. (f) Aurell M.J., Domingo L.R., Pérez P., Contreras R. // Tetrahedron. - 2004. - 60. - P. 11503.

10. Rankin K.N., Gauld J.W., Boyd R.J. // J. Phys. Chem. A - 2002. - 106. - P. 5155.

11. $W u$ P. // J. Struct. Chem. - 2013. - 54. - P. 983. (b) Wu P. // J. Struct. Chem. - 2014. - 55. - P. 147. (c) Wu P. // J. Struct. Chem. - 2014. - 55. - P. 515. (d) Wu P., Truong J., Huang Y., Li J. // J. Theor. Comput. Chem. - 2013. - 12. - P. 1350064. (e) Wu P., Chen X., Li J., Huang Y. // Comput. Theor. Chem. - 2014. - 1030. - P. 67. (f) Wu P., Li J. // J. Theor. Comput. Chem. - 2014. - 13. - P. 1450051.

12. Frisch M.J., Trucks G.W., Schlegel H.B., Scuseria G.E., Robb M.A., Cheeseman J.R., Montgomery J.A. Jr., Vreven T., Kudin K.N., Burant J.C., Millam J.M., Iyengar S.S., Tomasi J., Barone V., Mennucci B., Cossi M., Scalmani G., Rega N., Petersson G.A., Nakatsuji H., Hada M., Ehara M., Toyota K., Fukuda R., Hasegawa J., Ishida M., Nakajima T., Honda Y., Kitao O., Nakai H., Klene M., Li X., Knox J.E., Hratchian H.P., Cross J.B., Adamo C., Jaramillo J., Gomperts R., Stratmann R.E., Yazyev O., Austin A.J., Cammi R., Pomelli C., Ochterski J.W., Ayala P.Y., Morokuma K., Voth G.A., Salvador P., Dannenberg J.J., Zakrzewski V.G., Dapprich S., Daniels A.D., Strain M.C., Farkas O., Malick D.K., Rabuck A.D., Raghavachari K., Foresman J.B., Ortiz J.V., Cui Q., Baboul A.G., Clifford S., Cioslowski J., Stefanov B.B., Liu G., Liashenko A., Piskorz P., Komaromi I., Martin R.L., Fox D.J., Keith T., Al-Laham M.A., Peng C.Y., Nanayakkara A., Challacombe M., Gill P.M.W., Johnson B., Chen W., Wong M.W., Gonzalez C., Pople J.A. Gaussian 03, Revision B.03; Gaussian, Inc.: Pittsburgh, PA, 2003.

13. Gonzales C., Schlegel H.B. // J. Chem. Phys. - 1989. - 90. - P. 2154.

14. Gonzales C., Schlegel H.B. // J. Phys. Chem. - 1990. - 94. - P. 5523.

15. Hall N.E., Smith B.J. // J. Phys. Chem. A - 1998. - 102. - P. 4930. 